\title{
Vitamin A Receptors
}

\section{RETINOIC ACID BINDING IN OCULAR TISSUES}

\author{
By BARBARA WIGGERT, DONALD R. BERGSMA, RALPH HELMSEN \\ and GERALD J. CHADER \\ Laboratory of Vision Research and Clinical Branch, National Eye Institute, \\ National Institutes of Health, Bethesda, MD 20014, U.S.A.
}

(Received 16 May 1977)

\begin{abstract}
Analysis of the sucrose-density-gradient patterns of the $110000 \mathrm{~g}$ supernatant fractions of adult and foetal retina and pigment epithelium showed them to contain a limited number of highly specific binding sites ('receptors') for $\left[{ }^{3} \mathrm{H}\right] \mathrm{retinoic}$ acid that sediment at approx. 2S. Binding in pigment epithelium is higher than in any tissue yet reported. A $5 \mathrm{~S}$ binding component is also observed and is probably due to serum contamination. Fractionation studies indicate that $\left[{ }^{3} \mathrm{H}\right] \mathrm{retinoic}$ acid binding in the retina is lower in the photoreceptor units than in the retinal inner layers. This is in contrast with previous results that show greater $\left[{ }^{3} \mathrm{H}\right]$ retinol binding in photoreceptors. Studies with dystrophic human and rat retinas, which lack the photoreceptor layers, confirm that $\left[{ }^{3} \mathrm{H}\right]$ retinoic acid binding is greater in the non-photoreceptor layers of the retina. No specific $\left[{ }^{3} \mathrm{H}\right]$ retinoic acid binding is found in corneal epithelium, although endothelium and the conjunctiva demonstrate specific $2 \mathrm{~S}$ binding. Such differences in retinol and retinoic acid binding may indicate different roles for the two compounds in ocular tissues.
\end{abstract}

Vitamin A (retinol) has several functions in animal tissues. Besides its well-known role in vision, retinol is necessary for maintenance of spermatogenesis and pregnancy (Thompson et al., 1964) and for general growth and tissue development, especially in epithelial cells (Fell, 1957). Retinoic acid, a normal metabolite of retinol but one not stored in the body to any great extent, can replace retinol in many of these processes except those for vision and reproductive function (Roberts \& DeLuca, 1969).

Receptor macromolecules for retinoic acid have been found in several rat tissues (Ong \& Chytil, 1975) and in the bovine retina (Futterman et al., 1976; Saari \& Futterman, 1976a,b). These receptors exhibit high affinity and specificity for retinoic acid and appear to be different from retinol receptors, which are also present in many tissues. Since the tissues of the eye (retina, cornea etc.) are dependent on vitamin A for normal functioning, the present study was carried out to (1) investigate the possible presence of specific retinoic acid-binding species in several ocular tissues, (2) determine some of their characteristics and (3) compare the concentration of such binding species under normal adult, developmental and pathological conditions.

\section{Materials and Methods}

\section{Tissues}

Chicken and bovine tissues and serum were obtained fresh from local slaughterhouses. Eggs were from Truslow Farms, Chestertown, MD, U.S.A. Rhesus monkeys were normal adult animals from the National Institutes of Health (N.I.H.) animal colony. Human retinas were autopsy specimens from a 17year-old patient with acute lymphocytic leukaemia and a 59-year-old retinitis-pigmentosa patient with bronchogenic carcinoma (Bergsma et al., 1977). Normal Sprague-Dawley rats were used; retinaldystrophic rats were of the Royal College of Surgeons (R.C.S.) type maintained at N.I.H. Bovine serum was from fresh clotted blood obtained from a local slaughterhouse; purified bovine serum albumin was from Sigma Chemical Co., St. Louis, MO, U.S.A.

\section{Pigment epithelium}

Bovine pigment-epithelial cells were obtained in the following manner. Cornea, vitreous humour and retina were removed from the eye and a small amount of Tris buffer $(10 \mathrm{~mm}-\mathrm{Tris} / \mathrm{HCl}, \mathrm{pH} 7.6$, containing $1 \mathrm{~mm}$-EDTA, $10 \mathrm{~mm}-\mathrm{KCl}, 1 \mathrm{~mm}$-dithiothreitol) was poured into the remaining eye 'cup'. The pigmentepithelial cells were gently teased off the underlying choroid with a small camel's hair brush and concentrated by centrifugation before homogenization (Wiggert et al., 1976). Addition of iso-osmotic (0.9\%) saline had no effect on the process. When appropriate (see Fig. $3 a$ below), the amount of buffer was kept minimal and cells were directly homogenized in the isolating buffer without washing. In all other cases, 
the intact pigment epithelium-choroid unit was used after removal of the retina.

\section{Cornea}

Corneal epithelial and endothelial preparations were made as previously described (Wiggert et al., 1977a); bulbar conjunctiva was gently scraped from the surface of the rinsed intact eye in a circle about $5 \mathrm{~mm}$ from the limbus and processed in a manner similar to corneal epithelium.

\section{Retina fractionation}

In these studies, the retinas were gently vortexed $(2000 \mathrm{rev} . / \mathrm{min}$ for $1 \mathrm{~min})$ in a round-bottom centrifuge tube and centrifuged at $800 \mathrm{~g}$ for $5 \mathrm{~min}$. The resultant supernatant was removed from the pelleted inner layers of the retina ('rod-depleted' pellet) and centrifuged at $20000 \mathrm{~g}$ to obtain the crude photoreceptor fraction. The crude photoreceptor fraction, which contains mainly rod-outer-segment material (B. Wiggert, A. Mizukawa, T. Kuwabara \& G. Chader, unpublished work), and the outer-segment-poor 'rod-depleted' pellet were then individually homogenized and centrifuged at $110000 \mathrm{~g}$ to obtain the soluble supernatant fractions.

\section{Receptor studies}

The $110000 \mathrm{~g}$ supernatant fraction was prepared by homogenizing the particular tissue or tissue fraction in an all-glass homogenizer and centrifuging the homogenate at $110000 \mathrm{~g}$ for $60 \mathrm{~min}$ (Wiggert \& Chader, 1975). Portions $(0.25 \mathrm{ml})$ of the supernatant were incubated with appropriate amounts of radioactively labelled retinol or retinoic acid for $2 \mathrm{~h}$ at $4^{\circ} \mathrm{C}$. $\left[{ }^{3} \mathrm{H}\right]$ Retinoic acid (sp. radioactivity $37 \mathrm{Ci} / \mathrm{mmol}$ ) was a gift from Dr. W. E. Scott, Hoffman-La Roche Inc., Nutley, NJ, U.S.A. $\left[{ }^{3} \mathrm{H}\right]$ Retinol (sp. radioactivity $2.66 \mathrm{Ci} / \mathrm{mmol}$ ) was from New England Nuclear Corp., Boston, MA, U.S.A. Non-radioactively labelled compounds were from Sigma Chemical Co. All operations involving the radioactively labelled compounds were performed in the dark or in dim-red light. Samples were each layered on a separate linear sucrose gradient $[4.6 \mathrm{ml}$ of $5-20 \%(\mathrm{w} / \mathrm{v})$ sucrose in Tris buffer] and centrifuged for $16 \mathrm{~h}$ at $243000 \mathrm{~g}$. Approx. 35 fractions were collected per centrifuge tube, and radioactivity was determined with $15 \mathrm{ml}$ of Aquasol (New England Nuclear Corp.). $A_{280}$ was determined after addition of $0.75 \mathrm{ml}$ of water. Protein concentration was determined by the method of Lowry et al. (1951), with bovine serum albumin as standard.

\section{Results}

Bovine serum readily bound $\left[{ }^{3} \mathrm{H}\right]$ retinoic acid (Fig. 1). Neither non-radioactively labelled retinol

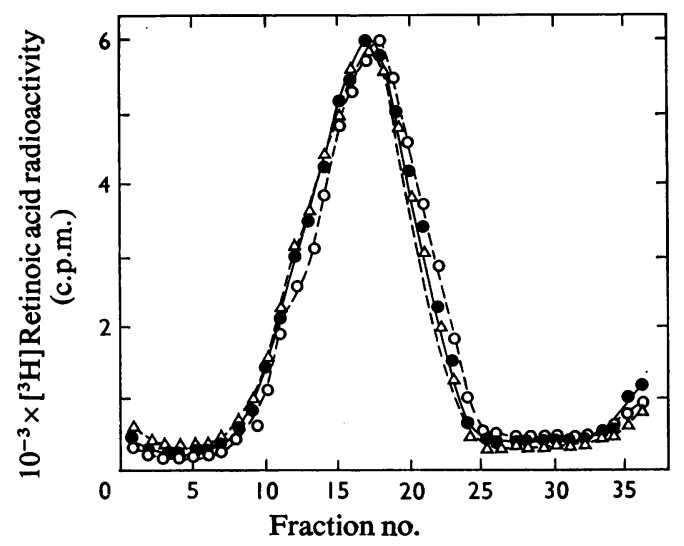

Fig. 1. Sucrose-density-gradient patterns of bovine serum Serum $(30 \mathrm{mg} / \mathrm{ml})$ with $20 \mathrm{~nm}-\left[{ }^{3} \mathrm{H}\right] \mathrm{retinoic}$ acid alone $(-)$ or in the presence of non-radioactively labelled retinoic acid $\left(20 \mu \mathrm{M}\right.$; $\left.0_{----O}\right)$ or of nonradioactively labelled retinol $(20 \mu \mathrm{M} ; \Delta----\Delta)$ was incubated for $2 \mathrm{~h}$ at $4^{\circ} \mathrm{C}$ in $10 \mathrm{~mm}$-Tris/ $\mathrm{HCl}$ buffer, pH7.6, containing $1 \mathrm{~mm}-\mathrm{EDTA}, 10 \mathrm{~mm}-\mathrm{KCl}$ and $1 \mathrm{~mm}$-dithiothreitol. Ultracentrifugation was for $16 \mathrm{~h}$ at $243000 \mathrm{~g}$. Duplicate centrifugation patterns were in close agreement $( \pm 10 \%)$.

nor retinoic acid at a 1000 -fold excess of concentration had any effect on the binding, indicating that a large number of relatively non-specific binding sites are available for retinoic acid interaction. The binding peak had a sedimentation coefficient of $5 \mathrm{~S}$ as does bovine serum albumin. In separate experiments, purified bovine serum albumin had identical binding characteristics (results not shown).

In contrast, the binding in retinal cytosol had a sedimentation coefficient of $2 S$ (Figs. $2 a$ and $2 b$ ). Non-radioactively labelled retinol had little effect on the binding of $\left[{ }^{3} \mathrm{H}\right] \mathrm{retinoic}$ acid, whereas the radioactively labelled peak was abolished in the presence of non-radioactively labelled retinoic acid. In Table $1(b)$, $\left[{ }^{3} \mathrm{H}\right] \mathrm{retinoic}$ acid binding in the retinal cytosol fractions of several species are compared. A small $5 \mathrm{~S}$ peak or shoulder was also observed in some retinal preparations (see Figs. $2 a$ and $2 b$ ) and was increased rather than diminished by the addition of non-radioactively labelled retinoic acid. It is likely that the $5 \mathrm{~S}$ binding was due to serum albumin, since it sedimented in a similar region of the gradient (Fig. 1). Moreover, displacement of $\left[{ }^{3} \mathrm{H}\right] \mathrm{retinoic}$ acid from a limited number of specific $2 \mathrm{~S}$ binding sites would naturally lead to increased uptake by lower-affinity, but highercapacity, 5S (albumin) binding sites.

No $\left[{ }^{3} \mathrm{H}\right]$ retinoic acid peak was observed in the cytosol preparation of bovine pigment-epithelial cells prepared by brushing the cells off the underlying 


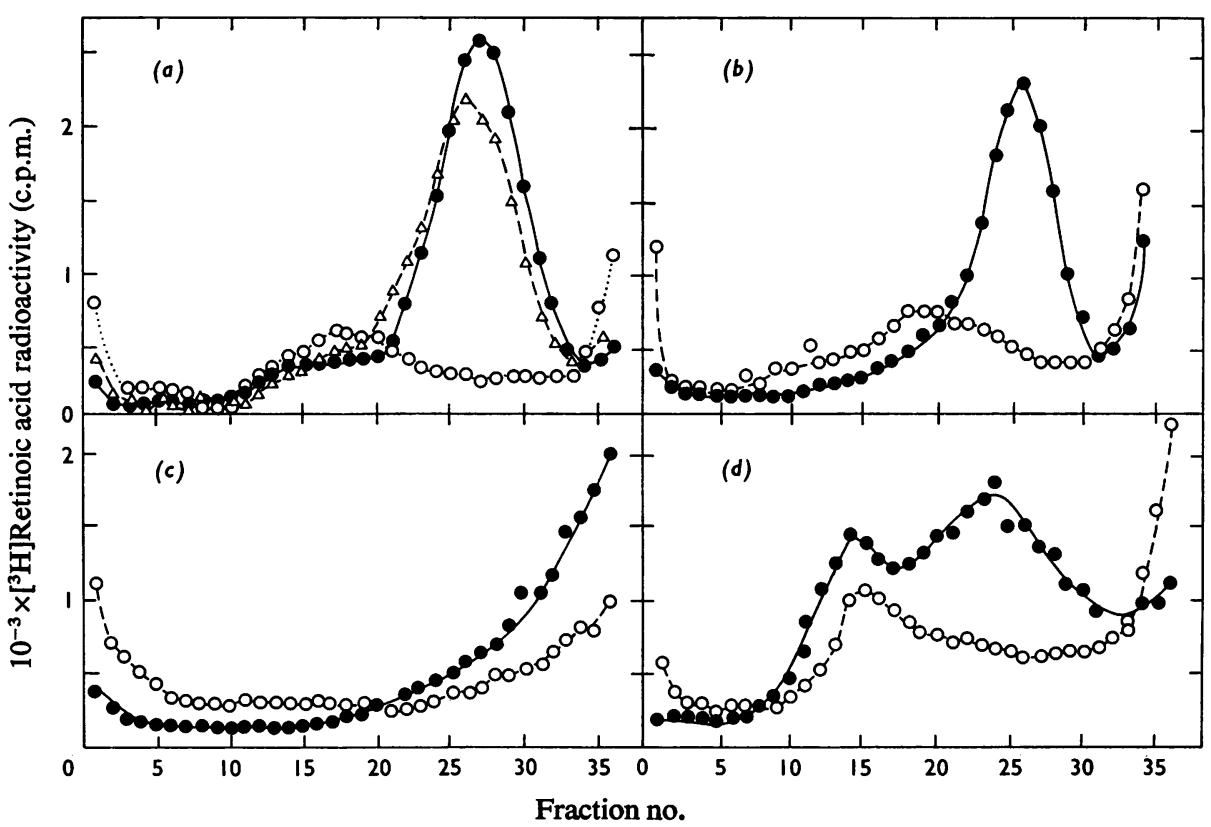

Fig. 2. Sucrose-density-gradient patterns of supernatant fractions

(a) Bovine retina $(11.2 \mathrm{mg}$ of protein $/ \mathrm{ml})$. (b) Rhesus monkey retina $(6.0 \mathrm{mg}$ of protein $/ \mathrm{ml})$. (c) Bovine pigment epithelium (1.1 mg of protein/ml). (d) Rhesus monkey pigment epithelium-choroid unit $(2.9 \mathrm{mg}$ of $\mathrm{protein} / \mathrm{ml})$. Incubation was carried out with $20 \mathrm{nM}-\left[{ }^{3} \mathrm{H}\right]$ retinoic acid alone $(-\bullet)$ or in the presence of non-radioactively labelled retinoic acid $\left(20 \mu \mathrm{M} ; \mathrm{O}_{----O}\right)$ or non-radioactively labelled retinol $(20 \mu \mathrm{M} ; \Delta----\Delta)$. Other conditions were as in Fig. 1.

choroid and pelleting them in the Tris buffer before homogenization (Fig. $2 c$ and Table $1 c$ ). Since added non-radioactively labelled retinoic acid slightly decreased $\left[{ }^{3} \mathrm{H}\right]$ retinoic acid binding in the $2 \mathrm{~S}$ region however, it seemed possible that some specific binding was, in fact, present in this area. Moreover, specific $\left[{ }^{3} \mathrm{H}\right]$ retinoic acid binding was readily apparent in the cytosol fraction of the entire pigment epitheliumchoroid unit of the Rhesus monkey (Fig. 2d). In this case, peaks of $5 \mathrm{~S}$ and $2 \mathrm{~S}$ were observed with saturable binding in the $2 \mathrm{~S}$ region as demonstrated by competition with non-radioactively labelled retinoic acid. Substantial $5 \mathrm{~S}$ binding was observed in most species examined, although only small amounts are present in human samples tested (Table $1 d$ ). The $5 \mathrm{~S}$ binding was not markedly affected by large amounts of nonradioactively labelled retinoic acid, which was also the case with serum albumin. Values for $2 \mathrm{~S}$ binding are difficult to determine accurately in some cases owing to the presence of substantial and overlapping 5S binding. Values given are thus only approximations, but they are consistent and quite reproducible (see standard deviation values given in Table 1). This problem is not general and is only observed in a few pigment epithelium-choroid unit preparations. It may be resolved in the future by refinement of the gradient technique.

The binding values given in Table 1 were determined in experiments with $20 \mathrm{nM}-\left[{ }^{3} \mathrm{H}\right]$ retinoic acid. In some experiments, $10 \mathrm{~nm}$ - or $40 \mathrm{~nm}-\left[{ }^{3} \mathrm{H}\right]$ retinoic acid was used; binding was linear with respect to concentration in this concentration range. For example, with bovine retina, values of $2.5,1.2$ and $0.64 \mathrm{pmol}$ bound $/ \mathrm{mg}$ of protein were calculated at concentrations of 40,20 and $10 \mathrm{nM}-\left[{ }^{3} \mathrm{H}\right]$ retinoic acid respectively. Similar results were obtained with chickembryo retina, monkey retina, foetal bovine retina and bovine corneal epithelium. The $2 \mathrm{~S}$ values for chick embryo pigment epithelium-choroid unit were $10.1,4.8$ and $2.7 \mathrm{pmol}$ bound $/ \mathrm{mg}$ of protein for the respective concentrations of $\left[{ }^{3} \mathrm{H}\right] \mathrm{retinoic}$ acid. Thus stoicheiometric binding of retinoic acid was observed under the present conditions.

Even though no distinct retinoic acid binding was observed in bovine pigment-epithelial cytosol prepared by the conventional 'brushing' method (Fig. $2 c$ ), both $2 \mathrm{~S}$ and $5 \mathrm{~S}$ peaks were readily apparent if the entire pigment epithelium-choroid unit was used 
Table 1. Tissue binding of $\left[{ }^{3} \mathrm{H}\right]$ retinoic acid

Supernatant fractions were incubated for $2 \mathrm{~h}$ at $4^{\circ} \mathrm{C}$ with $20 \mathrm{~nm}-\left[{ }^{3} \mathrm{H}\right]$ retinoic acid. Samples were subjected to sucrosedensity-gradient centrifugation [5-20\% (w/v) sucrose] for $16 \mathrm{~h}$ at $243000 \mathrm{~g}$. Values given are means \pm S.D. with each experiment consisting of duplicate gradients, e.g. when $n=6$, binding data from 12 separate gradients were averaged to obtain the mean value. When only one experiment was performed $(n=1)$, the duplicate values are both given. In some experiments, low levels of $5 \mathrm{~S}$ binding were difficult to quantify adequately and are given as less than $0.1 \mathrm{pmol} / \mathrm{mg}$ of protein $(<0.1)$ * indicates that no significant binding activity was observid under the present conditions. R.C.S. indicates Royal College of Surgeons-type retinal dystrophic rats.

\begin{tabular}{|c|c|c|c|c|}
\hline \multirow[b]{2}{*}{ Tissue } & \multirow[b]{2}{*}{ Species } & \multicolumn{2}{|c|}{$\begin{array}{c}\text { Bound }\left[{ }^{3} \mathrm{H}\right] \text { retinoic acid } \\
(\mathrm{pmol} / \mathrm{mg} \text { of protein) }\end{array}$} & \multirow{2}{*}{$\begin{array}{c}\text { No. of } \\
\text { experiments }\end{array}$} \\
\hline & & $2 S$ & $5 S$ & \\
\hline (a) Serum & Cow & $*$ & $0.4 \pm 0.0$ & 2 \\
\hline (b) Retina & $\begin{array}{l}\text { Cow } \\
\text { Monkey } \\
\text { Chicken } \\
\text { Human } \\
\text { Human (retinitis pigmentosa) } \\
\text { Chick embryo } \\
\text { Cow embryo }\end{array}$ & $\begin{array}{l}1.2 \pm 0.1 \\
2.6 \pm 0.3 \\
2.7 \pm 0.1 \\
2.4 \pm 0.2 \\
2.9,2.8 \\
1.6 \pm 0.1 \\
3.6 \pm 0.2\end{array}$ & $\begin{array}{l}<0.1^{*} \\
<0.1^{*} \\
{ }_{*}^{*} \\
* 0.1^{*}\end{array}$ & $\begin{array}{l}6 \\
2 \\
2 \\
2 \\
1 \\
8 \\
2\end{array}$ \\
\hline (c) Pigment epithelium & Cow & $*$ & * & 4 \\
\hline (d) Pigment epithelium-choroid & $\begin{array}{l}\text { Monkey } \\
\text { Chicken } \\
\text { Human } \\
\text { Human (retinitis pigmentosa) } \\
\text { Chick embryo } \\
\text { Cow embryo }\end{array}$ & $\begin{array}{l}5.3,6.0 \\
6.4 \pm 0.6 \\
4.6 \pm 0.2 \\
6.8 \pm 0.2 \\
4.8 \pm 0.4 \\
2.6 \pm 0.1\end{array}$ & $\begin{array}{l}2.9,3.2 \\
7.0 \pm 0.5 \\
* \\
* \\
2.2 \pm 0.3 \\
1.4 \pm 0.2\end{array}$ & $\begin{array}{l}1 \\
2 \\
2 \\
1 \\
5 \\
2\end{array}$ \\
\hline $\begin{array}{l}\text { (e) Pigment epithelium-choroid } \\
\text { Pigment epithelium } \\
\text { Choroid }\end{array}$ & Cow & $\begin{array}{l}1.5 \pm 0.3 \\
8.2 \pm 0.3 \\
0.9 \pm 0.2\end{array}$ & $\begin{array}{l}2.4 \pm 0.2 \\
2.3 \pm 0.3 \\
1.6 \pm 0.2\end{array}$ & $\begin{array}{l}3 \\
2 \\
2\end{array}$ \\
\hline $\begin{array}{l}\text { (f) Retina } \\
\text { Pellet } \\
\text { Photoreceptors }\end{array}$ & Cow & $\begin{array}{l}1.2 \pm 0.1 \\
1.9 \pm 0.1 \\
1.1 \pm 0.1\end{array}$ & $\begin{array}{l}<0.1_{*} \\
0.3 \pm 0.0\end{array}$ & $\begin{array}{l}3 \\
3 \\
3\end{array}$ \\
\hline $\begin{array}{l}\text { (g) Cornea } \\
\text { Epithelium } \\
\text { Endothelium } \\
\text { Conjunctiva }\end{array}$ & Cow & $\begin{array}{c}* \\
2.9 \pm 0.1 \\
1.4 \pm 0.1\end{array}$ & $\begin{array}{l}0.5 \pm 0.0 \\
* 0.4 \pm 0.0\end{array}$ & $\begin{array}{l}3 \\
2 \\
3\end{array}$ \\
\hline $\begin{array}{l}\text { (h) Retina + pigment epithelium- } \\
\text { choroid }\end{array}$ & Rat (normal) & $2.5 \pm 0.2$ & $4.2 \pm 0.5$ & 2 \\
\hline $\begin{array}{l}\text { Retina + pigment epithelium- } \\
\text { choroid }\end{array}$ & Rat (R.C.S.) & $3.1 \pm 0.1$ & $3.5 \pm 0.3$ & 2 \\
\hline Cerebrum & Rat (normal) & $1.9 \pm 0.0$ & $4.6 \pm 0.3$ & 2 \\
\hline Cerebrum & Rat (R.C.S.) & $2.1 \pm 0.1$ & $5.4 \pm 0.2$ & 2 \\
\hline
\end{tabular}

(Fig. 3a; Table 1e). When isolated pigment-epithelial cells were homogenized in the buffer that was used for isolation by 'brushing', substantial $2 \mathrm{~S}$ binding was observed (Fig. $3 a$ ). Choroid that had been somewhat depleted of adherent pigment-epithelial cells in this manner showed a greater decrease in $2 \mathrm{~S}$ than $5 \mathrm{~S}$ binding.

It was also of some interest to see if the $\left[{ }^{3} \mathrm{H}\right]$ retinoic acid receptor was localized in the rod-outer-segment fraction of the retina (Fig. $3 b$; Table $1 f$ ). In this experiment, retinas were gently vortexed to produce a crude outer-segment suspension and a relatively rod-poor or 'rod-depleted' pellet. No enhancement of $\left[{ }^{3} \mathrm{H}\right]$ retinoic acid binding was observed in the soluble proteins of the outer-segment fraction; rather the specific activity of $2 \mathrm{~S}$ binding was somewhat lower than either that seen with the whole retinal preparation or the rod-depleted pellet (Table $1 f$ ). It is noteworthy that $\left[{ }^{3} \mathrm{H}\right] \mathrm{retinoic}$ acid binding to a broad $5-8 \mathrm{~S}$ shoulder is accentuated in the outer-segment fraction. This may be related to a 7-8S retinolreceptor species that we have recently identified in 


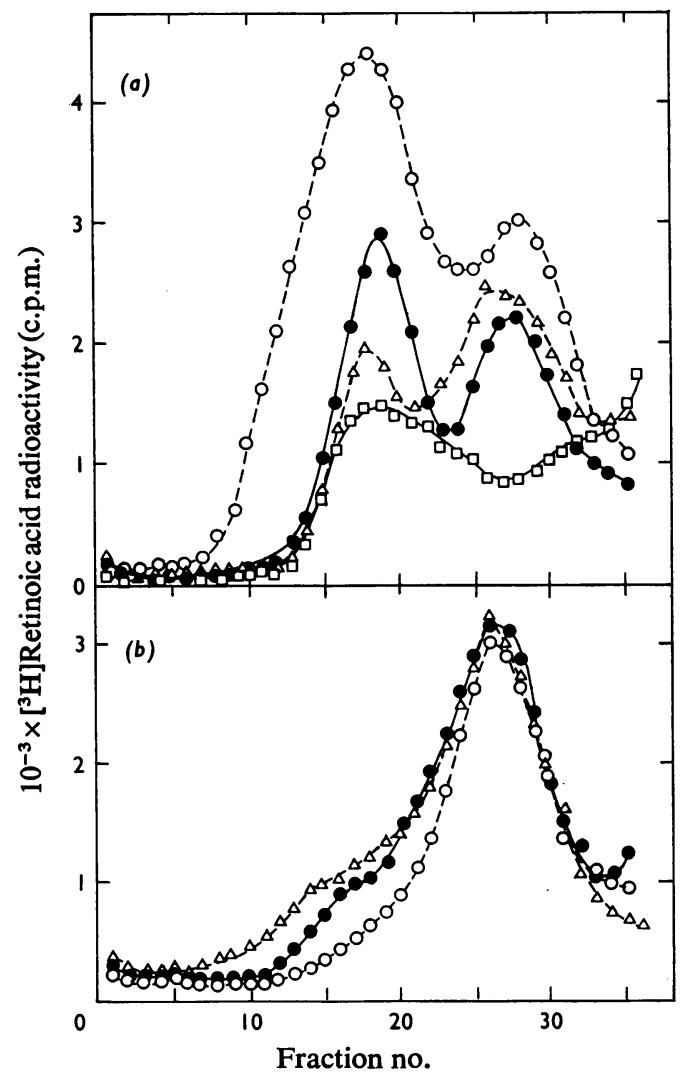

Fig. 3. Sucrose-density-gradient patterns of supernatant fractions

(a) Bovine pigment epithelium-choroid unit $(7.0 \mathrm{mg}$ of protein $/ \mathrm{ml}$ ) was incubated with $\left[{ }^{3} \mathrm{H}\right]$ retinoic acid (-) Bovine pigment-epithelial cells were isolated and homogenized in the same buffer at concentrations of $0.8 \mathrm{mg} / \mathrm{ml}$; incubation was carried out with $\left[{ }^{3} \mathrm{H}\right]$ retinoic acid alone $(40 \mathrm{~nm} ; \Delta----\Delta)$ or in the presence of non-radioactively labelled retinoic acid $(20 \mu \mathrm{M} ; \square---\square)$. Choroid (13.3 mg of protein $/ \mathrm{ml}$; O-- - O) that was brushed free of much of the pigment epithelium was used. (b) Bovine retinal homogenate $(13.2 \mathrm{mg}$ of protein $/ \mathrm{ml} ;-\longrightarrow)$ ). Crude rod outer segments $(12.5 \mathrm{mg}$ of protein $/ \mathrm{ml}$; $\Delta---\Delta)$. Rod-poor inner layers of retina $(8.2 \mathrm{mg}$ of protein/ml; O--- O). $20 \mathrm{~nm}-\left[{ }^{3} \mathrm{H}\right]$ retinoic acid was present. Other conditions were as in Fig. 1.

outer segments (Bergsma et al., 1977) and that shows some affinity for retinoic acid (Wiggert et al., 1977b).

Bovine corneal epithelial supernatant demonstrated a single $\left[{ }^{3} \mathrm{H}\right]$ retinoic acid peak at $5 \mathrm{~S}$; no $2 \mathrm{~S}$ binding peak was observed (Fig. $4 a$; Table $1 g$ ). The addition of an excess of non-radioactively labelled retinoic acid had no effect on $5 \mathrm{~S}\left[{ }^{3} \mathrm{H}\right]$ retinoic acid

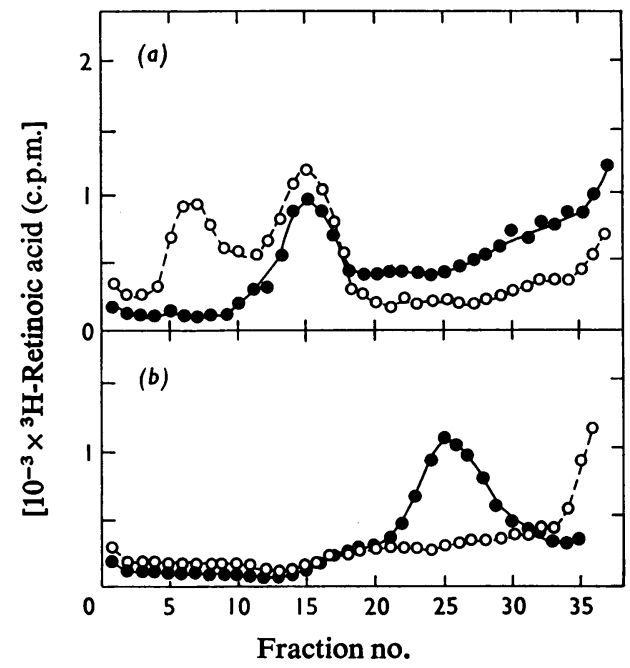

Fig. 4. Sucrose-density-gradient patterns of supernatant fractions

(a) Bovine corneal epithelium (25 $\mathrm{mg}$ of protein $/ \mathrm{ml}$ ).

(b) Bovine corneal endothelium (4.4 $\mathrm{mg}$ of protein/ $\mathrm{ml})$. Incubation was with $20 \mathrm{nM}-\left[{ }^{3} \mathrm{H}\right]$ retinoic acid alone (๑) or in the presence of non-radioactively labelled retinoic acid $(20 \mu \mathrm{M}$; O----O). Other conditions were as in Fig. 1.

binding but an additional, apparently non-specific, radioactively labelled peak appeared in the highmolecular-weight area of the gradient (Fig. 4a). In endothelial cytosol, only a $2 \mathrm{~S}$ receptor peak was observed which was abolished by excess of non-radioactively labelled retinoic acid (Fig. $4 b$ ). Bovine conjunctival cytosol also contained $2 \mathrm{~S}$ receptor macromolecules for both $\left[{ }^{3} \mathrm{H}\right]$ retinoic acid and $\left[{ }^{3} \mathrm{H}\right]$ retinol (Fig. 5). A small $5 \mathrm{~S}$ peak of bound $\left[{ }^{3} \mathrm{H}\right]$ retinoic acid (Fig. 5a) and $\left[{ }^{3} \mathrm{H}\right]$ retinol (Fig. $5 b$ ) was observed as well, but binding in this region was not suppressed by an excess of non-radioactively labelled vitamin. $\left[{ }^{3} \mathrm{H}\right]-$ Retinol binding in the $2 \mathrm{~S}$ region was greatly decreased in the presence of non-radioactively labelled retinol but not retinoic acid.

Embryonic tissues also exhibit $\left[{ }^{3} \mathrm{H}\right]$ retinoic acid binding. Chick retina (Fig. $6 a$ ) and pigment epithelium-choroid unit (Fig. 6b) cytosol preparations exhibited specific $2 \mathrm{~S}$ binding. Added excess of nonradioactively labelled retinoic acid virtually abolished the $2 \mathrm{~S}$ peak but had less effect on $5 \mathrm{~S}$ binding. Similar binding was observed in tissues of the foetal cow (Fig. $6 c$ ). As in the pigment-epithelium-choroid unit cytosol preparations of adult animals, 5S binding was observed in both foetal preparations. The $A_{\mathbf{2 8 0}}$ pattern of the foetal-cow retinal supernatant is given in Fig. 6(c) to demonstrate that the $2 \mathrm{~S}$ receptor peak is 


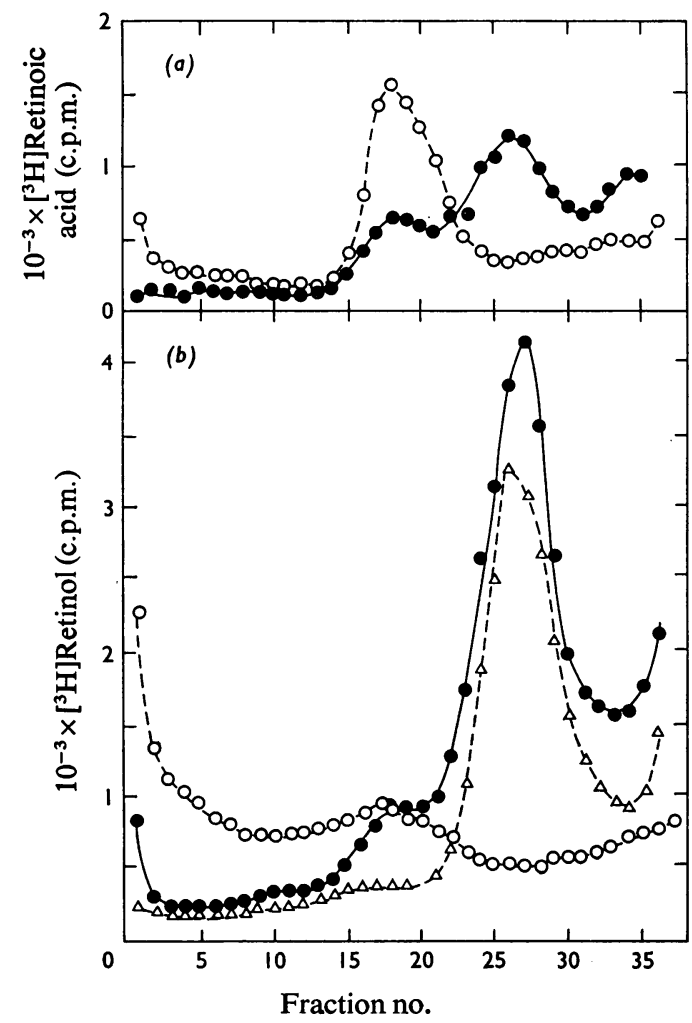

Fig. 5. Sucrose-density-gradient patterns of supernatant fractions of bovine conjunctiva

Bovine conjunctiva supernatant $(7.1 \mathrm{mg}$ of protein/ $\mathrm{ml}$ ) was incubated (a) with $20 \mathrm{~nm}-\left[{ }^{3} \mathrm{H}\right]$ retinoic acid alone (- ) or in the presence of non-radioactively labelled retinoic acid $\left(20 \mu \mathrm{M} ; \mathrm{O}_{---} \mathrm{O}\right)$ or (b) with $0.2 \mu \mathrm{M}-\left[{ }^{3} \mathrm{H}\right]$ retinol alone $(-\bullet)$ ) or in the presence of non-radioactively labelled retinol $(20 \mu \mathrm{M}$; $\mathrm{O}---\mathrm{O})$ or non-radioactively labelled retinoic acid $(20 \mu \mathrm{M} ; \Delta----\Delta)$. Other conditions were as in Fig. 1.

not simply due to a large peak of protein in that region of the gradient.

In the supernatant fraction of the combined retina, pigment epithelium and choroid of the normal adult albino rat, $2 \mathrm{~S}$ and $5 \mathrm{~S}$ binding species were observed; an almost identical pattern was observed in a similar preparation from the adult R.C.S. rat (Fig. 7a), where photoreceptors are virtually absent. Some care was taken in these experiments to match cytosol protein in the normal and R.C.S. rats. Cerebral brain tissue from the albino rat showed a considerably lower $2 \mathrm{~S}$ but a higher $5 \mathrm{~S}$ binding than in the retina (Fig. 7a). Human retina obtained at autopsy from a patient with advanced retinitis pigmentosa showed binding of $\left[{ }^{3} \mathrm{H}\right]$ retinoic acid qualitatively and quantitatively

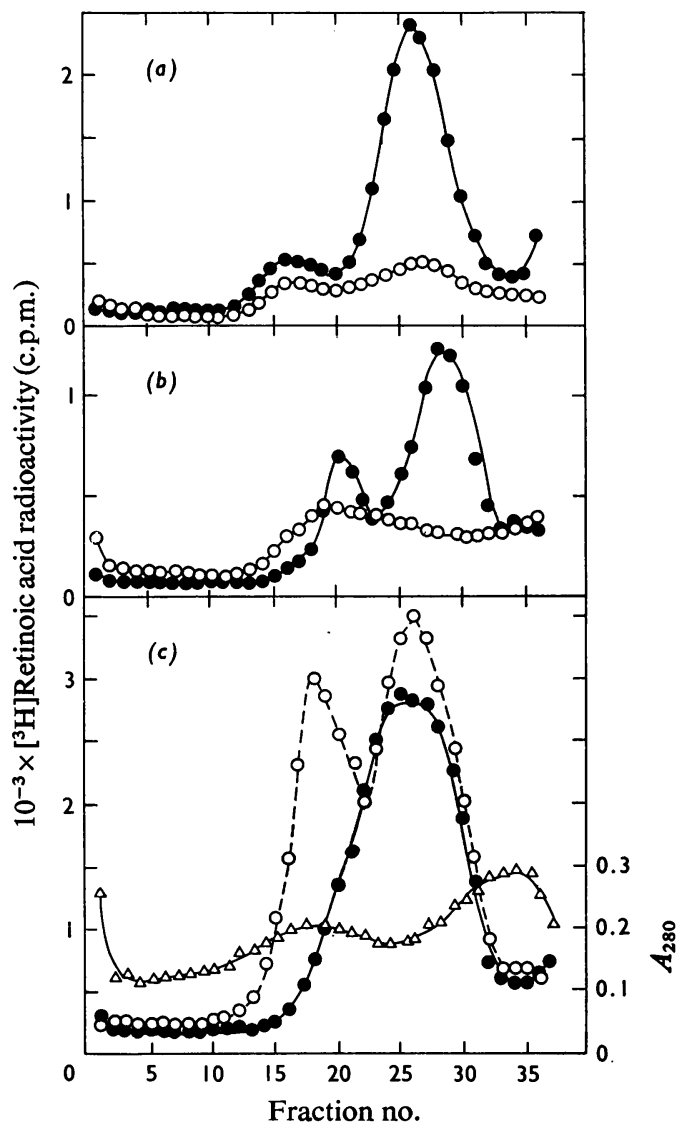

Fig. 6. Sucrose-density-gradient patterns of supernatant fractions of embryo retinas

(a) Chick-embryo retina $(10.8 \mathrm{mg}$ of protein $/ \mathrm{ml})$ was incubated with $10 \mathrm{~nm}-\left[{ }^{3} \mathrm{H}\right]$ retinoic acid alone $(-)$ ) or in the presence of non-radioactively labelled retinoic acid $(20 \mu \mathrm{M} ; \bigcirc----O)$. (b) Chickembryo pigment epithelium-choroid unit $(2.3 \mathrm{mg}$ of protein $/ \mathrm{ml}$ ) was incubated with $10 \mathrm{~nm}-\left[{ }^{3} \mathrm{H}\right]$ retinoic acid alone $(\bullet)$ or in the presence of nonradioactively labelled retinoic acid $(20 \mu \mathrm{M} ; \mathrm{O}----\mathrm{O})$. (c) Bovine-embryo retina $(4.4 \mathrm{mg}$ of protein $/ \mathrm{ml}$; - ) and pigment epithelium-choroid unit (7.0 $\mathrm{mg}$ of protein $/ \mathrm{ml} ; \bigcirc---O)$ were incubated with 10 nм- $\left[{ }^{3} \mathrm{H}\right]$ retinoic acid. $A_{280}$ of retinal supernatant was measured $(\triangle---\triangle)$. Other conditions were as in Fig. 1.

similar to that seen in normal human retina (Fig. 7b). Likewise, the pattern of binding in pigment epithelium-choroid supernatant from the retinitis pigmentosa patient was similar to that observed in the normal human tissues and as in retina, a somewhat higher specific activity for binding was observed (Fig. 7c). 


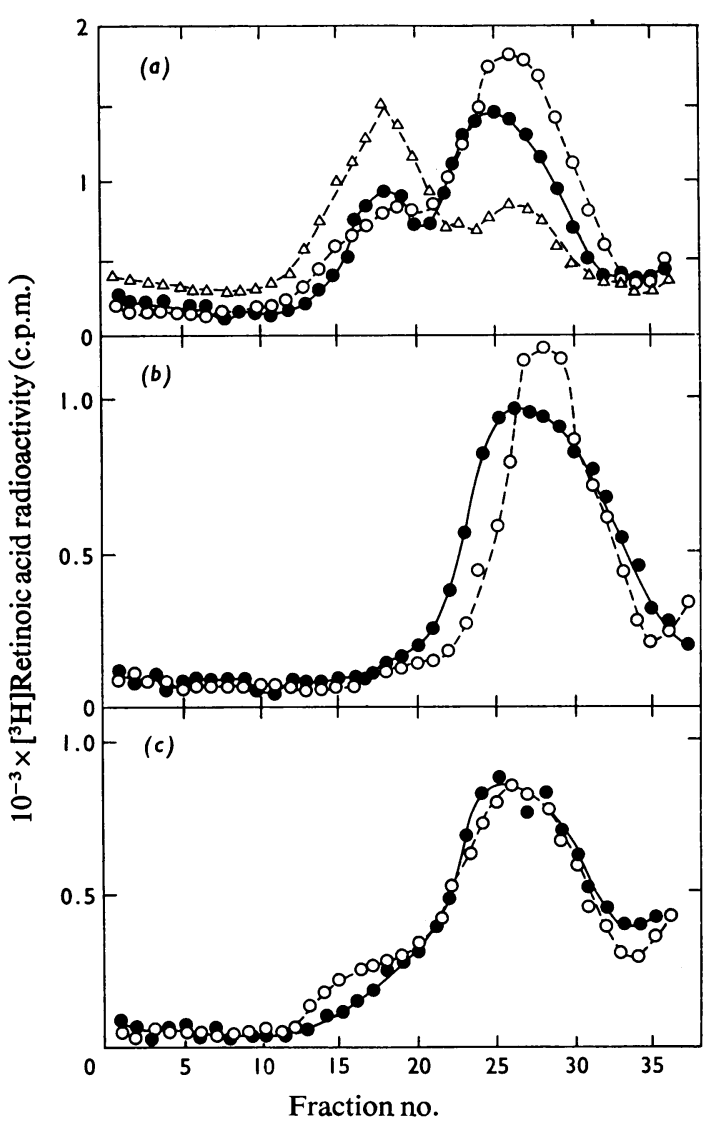

Fig. 7. Sucrose-density-gradient patterns of supernatant fractions

(a) Pigment epithelium-choroid unit from the retina of the normal albino rat $(4.7 \mathrm{mg}$ of protein $/ \mathrm{ml}$; - -$)$ and retinal dystrophic R.C.S. rat $(4.0 \mathrm{mg}$ of protein $/ \mathrm{ml}$; $\bigcirc----O)$, and normal rat brain $(4.7 \mathrm{mg}$ of protein $/ \mathrm{ml} ; \Delta----\Delta)$ were incubated together in the presence of $20 \mathrm{~nm}-\left[{ }^{3} \mathrm{H}\right]$ retinoic acid. (b) Normal human retina $(5.0 \mathrm{mg}$ of protein $/ \mathrm{ml}$; $-\infty)$ and retinitis pigmentosa retina $(5.4 \mathrm{mg}$ of protein $/ \mathrm{ml}$; O----O) were incubated with $10 \mathrm{~nm}-\left[{ }^{3} \mathrm{H}\right]$ retinoic acid. (c) Normal human pigment epithelium-choroid unit $(3.1 \mathrm{mg}$ of protein $/ \mathrm{ml}$; $-\bullet)$ and retinitis pigmentosa pigment epithelium-choroid unit $(2.0 \mathrm{mg}$ of protein $/ \mathrm{ml} ; \mathrm{O}_{----O}$ ) were incubated with $10 \mathrm{nM}-$ $\left[{ }^{3} \mathrm{H}\right]$ retinoic acid. Other conditions were as in Fig. 1.

\section{Discussion}

By the technique of sucrose-density-gradient analysis, only one specific $\left[{ }^{3} \mathrm{H}\right]$ retinoic acid-binding species was observed in retinal cytosol as shown by Saari \& Futterman $(1976 a, b)$ using DEAE-cellulose chromatography. This 'receptor' is small (2S) and demonstrates both high specificity and low capacity for retinoic acid binding, with a limited number of such binding sites available in the tissue. A highcapacity $5 \mathrm{~S}$ component is also observed by sucrosedensity-gradient analysis; it is quantitatively small in the retina but substantial in other tissues (as discussed below), and is most probably due to the presence of serum protein, i.e. albumin.

The $2 \mathrm{~S}$ retinoic acid receptor is separate and distinct from the $2 \mathrm{~S}$ retinol receptor, as shown by competition studies with non-radioactively labelled retinol and retinoic acid. It has a different pattern of distribution in the retina as well. Retinoic acid receptor is present in both photoreceptor units and other neural elements of the retina. This is in sharp contrast with $\left[{ }^{3} \mathrm{H}\right] \mathrm{retinol}$ receptors, which appear to be predominantly in photoreceptors (B. Wiggert, A. Mizukawa, T. Kuwabara \& G. Chader, unpublished work). These conclusions are substantiated by our studies on dystrophic retinas. The retinitis pigmentosa retina essentially lacks its outer segments and is thus a model for a 'rodless' retina (Bergsma et al., 1977). That the specific binding of $\left[{ }^{3} \mathrm{H}\right]$ retinoic acid is similar in normal and dystrophic retinas suggests that $\left[{ }^{3} \mathrm{H}\right]$ retinoic acid binding is rather similar in the photoreceptor and the non-photoreceptor regions of the retina. In contrast, the $7 \mathrm{~S}\left[{ }^{3} \mathrm{H}\right]$ retinol receptor is virtually absent from the retinitis pigmentosa retina (Bergsma et al., 1977). Similar conclusions can be drawn from studies on the R.C.S. rat, which also undergoes a degenerative loss of photoreceptor elements; binding in the degenerative retina-pigmentepithelial unit was somewhat greater than that seen in the normal unit.

$\left[{ }^{3} \mathrm{H}\right]$ Retinoic acid binding in 12-day-old chickembryo retina and in the pigment epitheliumchoroid unit is lower than in the adult chicken, whereas binding in bovine-embryo tissues is higher than in their adult counterparts. The significance of these differences is not yet known, but may involve differing signals for tissue growth or differentiation during development (Ong \& Chytil, 1976).

The pigment epithelium-choroid unit exhibits a high degree of binding, with both the specific saturable $2 \mathrm{~S}$ binding and the apparently non-specific $5 \mathrm{~S}$ binding greater than their counterparts in retina cytosol. High-specific-activity receptor binding is also apparent in isolated pigment-epithelial cells, when care is taken to retain the soluble proteins of the pigment cell during the isolation process. The lack of receptor in pigment-epithelial cells, isolated by the usual method, is consistent with the assumption that the small, soluble receptor is easily lost from the fragile pigment cells during isolation. It is unlikely that the $\left[{ }^{3} \mathrm{H}\right]$ retinoic acid binding observed in pigment epithelial cytosol is due to contaminating rod outer segments since $2 \mathrm{~S}$ binding is observed in good measure in the retinitis pigmentosa pigment epitheliumchoroid unit sample, where the photoreceptors are

Vol. 169 
virtually absent (Fig. 7c). Retinoicacid has been implicated in inherited storage diseases (Wolfe et al., 1977). It will be interesting to see if the high activity of retinoic acid receptor observed in the pigment epithelium-choroid unit of the retinitis pigmentosa patient can be correlated with the large amount of lipofucsin present in the pigment epithelium (Bergsma et al., 1977).

Retinol, retinoic acid and their derivatives are potent agents for controlling cell function and differentiation in many epithelial tissues (Sporn et al., 1976). The lack of a specific $2 \mathrm{~S}\left[{ }^{3} \mathrm{H}\right]$ retinoic acid receptor in corneal epithelium is somewhat surprising therefore, and contrasts sharply with its presence in corneal endothelium. The lack of $2 \mathrm{~S}\left[{ }^{3} \mathrm{H}\right] \mathrm{retinoic}$ acid receptor is all the more striking since the receptor species is found in good measure in conjunctiva, a similar although non-transparent cell layer. As shown in the present and previous studies (Wiggert et al., 1977a), all three cell layers (epithelial, endothelial and stromal) exhibit specific $2 \mathrm{~S}$ retinol binding. The cornea is usually thought of as one 'tissue'; the present data, as well as other work from our laboratory (Wiggert et al., 1977a), however, indicate the possibility of significant differences in handling vitamin A-type compounds in the different layers of the cornea. Study of receptor differences in corneal layers and in other tissues of the eye may thus contribute to the elucidation of the mechanism of action of retinol and its derivatives in maintaining normal function in ocular and other tissues.

\section{References}

Bergsma, D., Wiggert, B., Funahashi, M., Kuwabara, T. \& Chader, G. (1977) Nature (London) 265, 66-67

Fell, H. (1957) Proc. R. Soc. London Ser. B 146, 242-256

Futterman, S., Saari, J. \& Swanson, D. (1976) Exp. Eye Res. 22, 419-424

Lowry, O. H., Rosebrough, N. J., Farr, A. L. \& Randall, R. J. (1951) J. Biol. Chem. 193, 265-275

Ong, D. \& Chytil, F. (1975) J. Biol. Chem. 250, 6113-6117

Ong, D. \& Chytil, F. (1976) Proc. Natl. Acad. Sci. U.S.A. 73, 3976-3978

Roberts, A. \& DeLuca, H. (1969) in The Fat-Soluble Vitamins (DeLuca, H. \& Suttie, J., eds.), pp. 227-240, University of Wisconsin Press, Madison

Saari, J. \& Futterman, S. (1976a) Exp. Eye Res. 22, 425433

Saari, J. \& Futterman, S. (1976b) Biochim. Biophys. Acta 444, 789-793

Sporn, M., Dunlop, N., Newton, D. \& Smith, J. (1976) Fed. Proc. Fed. Am. Soc. Exp. Biol. 35, 1332-1338

Thompson, J., Howell, J. \& Pitt, G. (1964) Proc. R. Soc. London Ser. B 159, 510-535

Wiggert, B. \& Chader, G. (1975) Exp. Eye Res. 21, 143-151

Wiggert, B., Bergsma, D. \& Chader, G. (1976) Exp. Eye Res. 22, 411-418

Wiggert, B., Bergsma, D., Helmsen, R., Alligood, J., Lewis, M. \& Chader, G. (1977a) Biochim. Biophys. Acta 491, 104-113

Wiggert, B., Bergsma, D., Lewis, M. \& Chader, G. (1977b) J. Neurochem. 29, 947-954

Wolfe, L., Kin, N.,Baker, R., Carpenter, S. \& Andermann, F. (1977) Science 195, 1360-1362 